\title{
ANALISIS STRUKTURAL DAN NILAI PENDIDIKAN NOVEL GEDHONG SETAN KARYA SUPARTO BRATA SERTA RELEVANSINYA SEBAGAI MATERI PEMBELAJARAN NOVEL BERBAHASA JAWA
}

\section{Muhammad Fadli, Budi Waluyo*, dan Edy Suryanto.}

\author{
FKIP Universitas Sebelas Maret
}

\begin{abstract}
Abstrak: Karya sastra memiliki nilai-nilai penting yang dapat diterapkan dalam kehidupan salah satunya novel berbahasa Jawa. Oleh karena itu, peneliti ingin meneliti novel Gedhong Setan karya Suparto Brata. Penelitian ini bertujuan untuk mendeskripsikan: (1) Unsur struktural yang membangun novel, baik unsur intrinsik dan unsur ekstrinsik; (2) Nilai pendidikan yang terdapat dalam novel; dan (3) Relevansi novel sebagai materi pembelajaran novel berbahasa Jawa. Penelitian ini menggunakan penelitian kualitatif deskriptif dengan pendekatan struktural. Data yang diperoleh berasal dari novel, wawancara dengan ahli sastra, guru bahasa Jawa, dan siswa. Teknik pengambilan sampel menggunakan purposive sampling. Teknik pengumpulan data menggunakan analisis sumber tertulis atau dokumen dan wawancara. Uji validitas data menggunakan triangulasi sumber dan teori. Teknik analisis data menggunakan teknik analisis jalinan, yaitu reduksi data, penyajian data, penarikan simpulan. Simpulan penelitian ini; (1) Novel Gedhong Setan karya Suparto Brata memiliki unsur intrinsik meliputi tema, tokoh dan penokohan, alur, latar, bahasa, dan sudut pandang; sedangkan unsur ekstrinsik meliputi situasi sosial politik, ekonomi, dan budaya; sistem pengarang dan kepengarangan; sistem penerbit dan penerbitan; serta sistem pembaca; (2) Nilai-nilai pendidikan yang terdapat di dalam novel, yaitu: nilai keagamaan, nilai kesusilaan (moral), nilai sosial, dan nilai kultural; dan (3) Novel tersebut sangat relevan sebagai materi ajar dalam pembelajaran novel berbahasa Jawa di SMA.
\end{abstract}

Kata kunci: pendekatan struktural, novel, nilai pendidikan, materi pembelajaran

\begin{abstract}
Literary has important values that can be applied to life one of them is in Javanese language novel. Because of that, researcher want to research novel novel "Gedhong Setan" by Suparto Brata. This research aims to describe: (1) The structural elements which build this novel; (2) Educational elements in this novel; and (3) The Novel's relevance as Javanese educational
\end{abstract}


materials. Structural approach technique is used in this descriptive-qualitative research. The source of data descended from the novel; It also seeks the data by interviewing the Literary scholar, the teacher and the students. The researcher used purposive sampling. The technique of collecting the data requires document analysis and interview. Triangulation source and theory is applied to validity the data. The analysis done by some steps; the reduction, the presentation and the drawing of conclusion. The conclusion of this research: (1) Novel "Gedhong Setan" by Suparto Brata have the intrinsic elements: theme, character and characteristic, plot, setting, language, and point of view. The extrinsic elements: social-politic, economic and culture condition; author system, publisher and publishing system; and the readers' rule; (2) Education values: religious, moral, social, and cultural value; (3) Relevance for education as material of Javanese Language in Senior High School.

Keywords: $\quad$ structural approach, novel, education value, teaching materials

\section{PENDAHULUAN}

Pendidikan merupakan cara untuk mencerdaskan bangsa yang sesuai dengan pembukaan Undang-Undang Dasar 1945 alinea ke-4 serta ingin mencapai tujuan pendidikan nasional. Pada tujuan pendidikan nasional diharapkan masyarakat dapat mengembangkan potensi yang ada di dalam dirinya yang tidak lupa menjadikan masyarakat yang bermoral dan beretika. Nilai moral dan etika tersebut dapat diperoleh salah satunya di dalam karya sastra. Karya sastra lahir tidak semata-mata hasil dari pengarang, namun merupakan perwujudan dari fenomena kehidupan masyarakat. Fenomena tersebut dapat berupa masyarakat sebagai sumber cerita pada karya sastra, maupun bentuk respons dan gambaran masyarakat yang kemudian dikemas dan dituangkan dalam bahasa yang indah.

Karya sastra dibagi menjadi tiga jenis, yaitu: prosa, puisi, dan drama. Prosa terbagi menjadi dua, yaitu novel dan cerpen. Novel merupakan hasil cipta sastra yang menggambarkan kehidupan manusia yang berinteraksi dengan manusia lain dalam suatu komunitas masyarakat, sehingga mewujudkan cerita. Perbedaan novel dengan cerpen terletak pada panjang penceritaannya, di mana pada cerpen penceritaannya lebih ringkas, masalahnya lebih padu, dan plotnya 
tunggal (Rokhmansyah, 2014: 32). Interaksi antara manusia dalam cerita novel akan menimbulkan konflik. Novel juga mengangkat realita kehidupan dalam dunia imajinasi (Setyawati, 2013: 2). Melalui bahasa yang digunakan dapat diketahui ciri khas pengarang, tema, karakter tokoh, serta amanat yang termuat di dalamnya. Pesan moral dan kritik sosial banyak ditemukan di dalam karya sastra. Novel merupakan salah satu bentuk karya sastra yang banyak digemari oleh penikmat sastra di mana di dalamnya berisi gagasan dan pikiran pengarang yang imajinatif yang mengisahkan problematika kehidupan masyarakat.

Sebuah karya sastra dalam hal ini adalah novel memiliki unsur struktural yang terdiri dari unsur intrinsik dan ekstrinsik. Hal ini sesuai dengan pendapat yang dikemukakan oleh Suroto (1990: 87) bahwa unsur intrinsik adalah unsur dalam karya sastra yang ikut mempengaruhi terciptanya karya sastra, sedangkan unsur ekstrinsik adalah unsur luar sastra yang ikut mempengaruhi terciptanya karya sastra. Menurut Hawkes (dalam Pradopo, 2013: 75), prinsip strukturalisme merupakan struktur yang unsur- unsurnya saling berhubungan dengan erat dan tiap unsur memilki makna yang ada kaitannya dengan unsur lainnya dan keseluruhannya. Begitu juga unsurunsur yang saling berkaitan pada karya sastra novel memiliki struktur pembangunnya.

Menurut Utomo (2002: 137186), struktur internal sastra Jawa berbentuk buku yang bersifat picisan adalah tema, tokoh dan penokohan, alur, latar, bahasa, sudut pandang. Bahasa yang dimaksud bukanlah merupakan gaya bahasa, namun yang dimaksudkan ialah ragam pemakaian bahasa yang digunakan oleh pengarang. Berkenaan dengan unsur tersebut, Stanton (dalam Suwondo, 2001: 56) menyatakan bahwa dalam lingkup fiksi, unsur-unsur struktur karya sastra itu terdiri atas tema, fakta cerita, dan sarana sastra. Fakta cerita itu terdiri atas alur, tokoh, dan latar; sedangkan sarana sastra biasanya terdiri atas sudut pandang, gaya bahasa dan suasana, simbol, imaji, dan juga cara-cara pemilihan judul.

Di dalam karya sastra, fungsi sarana sastra adalah memadukan fakta sastra dengan tema sehinggga makna karya sastra tersebut dapat dipahami dengan jelas. Adapun struktur eksternal- 
nya berupa situasi sosial politik, ekonomi, dan budaya; sistem pengarang dan kepengarangan; sistem penerbit dan penerbitan; serta sistem pembaca. Pada penelitian ini juga, peneliti merujuk dan menggunakan analisis internal (intrinsik) dan eksternal (ekstrinsik) novel menurut Utomo dalam buku Eskapisme Sastra Jawa, di mana buku tersebut mengacu pada analisis yang dikemukakan oleh Lucien Goldmann dalam teori makrosastra.

Sebuah karya satra selain memiliki unsur struktural di dalamnya juga terkandung nilai pendidikan. Nilai adalah sesuatu yang berharga, bermutu, menunjukkan kualitas, dan berguna bagi manusia. Sesuatu itu bernilai berarti sesuatu itu berharga atau berguna bagi kehidupan manusia. Darmodiharjo (dalam Setiadi, 2006: 117) mengungkapkan nilai adalah sesuatu yang berguna bagi manusia baik jasmani maupun rohani.

Pendidikan pada hakikatnya merupakan upaya membantu peserta didik untuk menyadari nilai-nilai yang dimilikinya dan berupaya memfasilitasi mereka agar terbuka wawasan dan perasaannya untuk memiliki dan meyakini nilai yang lebih hakiki, lebih tahan lama, dan merupakan kebenaran yang dihormati dan diyakini secara sahih sebagai manusia yang beradab (Setiadi, 2006: 114). Ki Hajar Dewantara (dalam Rohman, dan Amri 2013: 8) mengartikan pendidikan sebagai usaha menuntun segenap kekuatan yang ada pada anak baik sebagai individu manusia maupun sebagai anggota masyarakat agar dapat mencapai kesempurnaan hidup. Mengacu pada uraian tentang pengertian nilai dan pengertian pendidikan di atas, dapat ditarik kesimpulan bahwa nilai pendidikan adalah segala sesuatu yang baik maupun buruk yang berguna bagi kehidupan manusia yang diperoleh melalui proses pengubahan sikap dan tata laku dalam upaya mendewasakan diri.

Sebuah karya sastra khususnya novel Jawa dapat dijadikan materi ajar dalam pembelajaran bahasa Jawa di SMA dengan kriteria antara lain: memiliki kelengkapan unsur, menyiratkan nilai pendidikan, menggunakan bahasa yang baik dan benar, serta tidak menggunakan bahasa vulgar. Materi ajar adalah segala bentuk materi yang digunakan untuk membantu guru melaksanakan kegiatan belajar- 
mengajar. Materi ajar atau bahan ajar adalah sesuatu yang mengandung pesan yang akan disampaikan dalam proses belajar-mengajar. Bahan ajar dikembangkan berdasarkan tujuan pembelajaran. Bahan ajar sastra yang ideal adalah bahan yang autentik, artinya benar-benar berupa karya cipta sastra. Karya sastra tersebut dapat berupa puisi, cerpen, novel, drama yang ditulis oleh sastrawan atau tulisan sendiri oleh guru (Ismawati, 2013: 35).

Pendidikan dalam Kurikulum 2013 untuk anak Sekolah Menengah Atas (SMA) pada kelas XI terdapat Kompetensi Dasar (KD) membaca novel. Pada KD membaca novel ini dapat sebagai pembanding karya sastra, yakni novel berbahasa Jawa dengan novel modern berbahasa Indonesia bahwa novel berbahasa Jawa juga memiliki nilai-nilai pendidikan yang umumnya terdapat pada masyarakat Jawa. Untuk mengetahui dan memahami nilai-nilai pendidikan atau pesan dari sebuah novel, diperlukan pemahaman mengenai isi novel tersebut salah satunya dengan menggunakan pendekatan struktural.

\section{METODE PENELITIAN}

Penelitian ini merupakan penelitian deskriptif kualitatif yang mendasarkan pada teori Bogdan dan Taylor (1993: 30) dan Asmani (2011: 75), yaitu mengkaji karya sastra berbentuk teks dokumen berupa novel. Karena itu, penelitian ini bersifat fleksibel, tidak terikat oleh tempat dan waktu. Penelitian ini menggunakan pendekatan strukturalisme.

Teknik yang digunakan untuk pengambilan sempel penelitian ini adalah purposive sampling. Patton (dalam Sutopo, 2002: 56) menyatakan bahwa purposive sampling adalah pemilihan sempel yang disesuaikan dengan masalah, kebutuhan, dan kemantapan peneliti dalam memperoleh data. Peneliti mengambil sampel berdasarkan tujuan penelitian, yaitu hasil wawancara guru mata pelajaran Bahasa Jawa dan beberapa siswa kelas XI di SMA Negeri 2 Surakarta. Sumber data penelitian ini digali dari narasumber dan dokumen.

Pengumpulan data dilakukan dengan teknik analisis dokumen dan wawancara. Dokumen merupakan barang-barang tertulis (Zuldafrial \& Lahir, 2012: 68), yaitu berupa novel Gedhong Setan karya Suparto Brata, 
buku-buku pendukung, jurnal, sumber online, dan sumber-sumber yang berkaitan dengan masalah yang dianalisis. Data yang diperoleh dalam penelitian ini juga berasal dari wawancara dengan narasumber.

Validitas data yang digunakan dalam penelitian ini, yaitu triangulasi teori dan sumber dengan mengacu teori yang dikemukakan oleh (Moleong, 2001: 178). Triangulasi teori digunakan dengan cara rujuk silang antarteori (teori satu dengan yang lain) untuk mendapatkan teori yang benar-benar terpercaya agar dapat digunakan sebagai acuan dalam penelitian. Adapun triangulasi sumber, yaitu teknik pemeriksaan kebenaran data hasil analisis dengan mewawancarai sumber yang berbeda tetapi membahas masalah yang sama. Hal ini bertujuan untuk memperoleh pandangan lain sehingga dapat ditarik kesimpulan lebih utuh. Teknik analisis data yang digunakan dalam penelitian ini adalah teknik analisis mengalir (flow model of analysis) yang meliputi tiga komponen, yaitu (1) reduksi data (data reduction), (2) sajian data (data display), (3) penarikan simpulan (concluting drawing) (Miles \& Huberman, 1992: 18).

\section{PEMBAHASAN}

Struktur Novel Gedhong Setan Karya Suparto Brata

Isi cerita dari novel Gedhong Setan karya Suparto Brata ini menceritakan tentang perjuangan anak pribumi yang sekolah di sekolahan Belanda dan sedikit kisah asmara yang dibumbui dengan hal-hal misteri yang menakutkan dan berlatarbelakang jaman penjajahan bangsa Belanda dan bangsa Jepang. Kisah novel ini dimulai dari Totje seorang anak bangsawan jawa/pribumi yang sedang menunggu hujan reda untuk malaksanakan janjinya dan sedang merasa jatuh cinta dengan seorang gadis anak belanda. Totje juga salah satu anak pribumi yang bisa sekolah di sekolahan elit belanda, yang mana dia bersikeras tidak mau kalah dengan para anak belanda. Totje merupakan anak pribumi yang pintar dan cerdas serta memiliki daya juang yang tinggi, karena semangat juangnya untuk mengutamakan sekolah dia harus gagal percintaanya dengan gadis belanda bernama Soniahenie Heuvelmen. 
Semangat juang dan sifat yang mendasari pokok pembicaraan pemberaninya itu pada akhirnya dalam suatu novel. Putra \& Harmengantarkanya menjadi pahlawan diwidjaja (2007: 94) mengatakan bahwa bagi keluarganya karena sudah menjadi pada dasarnya tema pada suatu cerita anak yang membanggakan orangtuanya serta bagi pemerintah pada saat itu karena berhasil menguak mata-mata dari musuh pemerintah.

Struktur yang terdapat dalam novel Gedhong Setan karya Suparto Brata adalah struktur intrinsik dan struktur ekstrinsik. Menurut Utomo (2002: 137-186), dalam bukunya Eskapisme Sastra Jawa unsur intrinsik meliputi tema, tokoh dan penokohan, alur, latar, bahasa, dan sudut pandang. Bahasa yang dimaksud bukanlah merupakan gaya bahasa namun yang dimaksudkan, yaitu ragam pemakaian bahasa yang digunakan oleh pengarang; sedangkan unsur ekstrinsik berupa situasi sosial politik, ekonomi, dan budaya; sistem pengarang dan kepengarangan; sistem penerbit dan penerbitan; serta sistem pembaca.

\section{Struktur Instrinsik}

Setiap cerita dalam karya sastra seperti novel, terdapat tema yang menjadi dasar cerita dalam karya sastra. Tema sendiri merupakan gagasan dasar memiliki makna yang terkandung di dalamnya. Dari dasar cerita inilah, terdapat makna yang disebut dengan tema. Tema yang diangkat dalam novel Gedhong Setan karya Suparto Brata adalah tema sosial dengan sub tema perjuangan dan percintaan yang dialami oleh Sidharta/Totjhe sebagai tokoh utama. Kisah tersebut dimulai dari kebimbangan Totjhe yang menunggu hujan tidak kunjung reda dan kedatangan dua temannya dari Belanda bahwa mereka akan ikut dengan Totjhe masuk kedalam Gedhong Setan. Dari cerita inilah awal konflik cerita dimulai.

Tokoh-tokoh cerita menurut Wahyuningtyas \& Santoso (2011: 3) dalam sebuah fiksi dibedakan menjadi: (1) Tokoh utama dan tokoh tambahan. Tokoh utama adalah tokoh yang diutamakan penceritaannya dalam prosa yang bersangkutan. Ia merupakan tokoh yng paling banyak diceritakan, baik sebagai pelaku kejadian maupun yang dikenai kejadian. Tokoh tambahan adalah tokoh yang tidak sentral kedudukannya dalam cerita tetapi 
kehadirannya sangat diperlukan untuk mendukung tokoh utama. (2) Tokoh Protagonis dan Tokoh Antagonis. Tokoh protagonis adalah tokoh yang memegang peranan pemimpin dalam cerita. Tokoh ini adalah tokoh yang menampilkan sesuatu sesuai dengan pandangan kita, harapan-harapan kita, dan merupakan pengejawantahan norma-norma, nilai-nilai yang ideal bagi kita. Adapun tokoh antagonis adalah tokoh penentang dari tokoh protagonis sehingga menyebabkan konflik dan ketegangan. Secara keseluruhan terdapat dua puluh tokoh yang terdapat dalam novel Gedhong Setan karya Suparto Brata. Tokoh sentral yang terdapat dalam novel adalah tokoh Totjhe, Mami, Soniahenie dan Jaan Van Vliet. Tokoh ini yang mempengaruhi jalannya cerita. Tokoh Totjhe yang termasuk tokoh utama dalam novel ini juga merupakan tokoh protagonis. Ia juga menjadi tokoh yang selalu diceritakan dalam novel Gedhong Setan. Tokoh Soniahenie juga berperan sebagai tokoh utama sebab dalam cerita ia merupakan tokoh yang menjadi penyebab konflik batin percintaan Totjhe. Kemudian tokoh Mami juga sebagai tokoh protagonis karena selalu mendukung Totjhe. Sedangkan, tokoh yang menentang jalannya cerita diperankan oleh Jaan Van Vliet. Klasifikasi tokoh bawahan dalam novel ini diperankan oleh Sopir Dhokar, Hendriks de Zwarver, Bram de Jong, Karel Hoekyus, Martin Steendam. Klasifikasi penokohan tersebut selaras dengan pendapat Waluyo (1994: 167) yang membagi tokoh berdasarkan fungsi yakni tokoh sentral dan tokoh bawahan. Selain itu, tokoh-tokoh lain yang terdapat dalam novel adalah Tineke, Henriette, Ivonny, Bob Roedmaker, Pak Polisi, Pak dokter, Rama, Meneer Heuvelman, Ben Rosenberg, Wong lanang wadon Jepang.

Dalam novel Gedhong Setan karya Suparto Brata alur digambarkan secara campuran. Alur yang digunakan dalam novel terdapat alur maju dan alur mundur. Semi (1993: 4) mengatakan bahwa alur sebuah cerita terdiri dari alur buka, alur tengah, alur puncak, dan alur tutup. pada tahap alur buka dikisahkan dengan penantian Totjhe terhadap hujan yang tak kunjung reda dan kedatangan dua temanya dari bangsa Belanda. Tahap alur tengah, cerita mulai memuncak dan terjadi alur mundur. 
Permasalahan antara tokoh dimulai ketika sudah masuk di dalam Gedhong Setan. Hal-hal yang dialami oleh Totjhe selalu mirip apa yang dia bayangkan dan selalu menegangkan. Tahap alur puncak terjadi konflik yang memuncak yang dialami oleh tokoh utamanya yakni tokoh Totjhe. Hal tersebut ditandai dengan jeritan-jeritan Soniahenie yang akan diperkosa oleh Jaan Van Vliet. Dari hal-hal inilah terjadi alur mundur dengan menceritakan tentang sosok Jaan yang disangka brandalan dari pelabuhan yang mempunyai komplotan penyelundup yang ada di dalam Gedhong Setan. Selanjutnya, pada tahap alur tutup ditandai dengan sadarnya Totjhe di sebuah rumah sakit yang disambut banyak orang bak pahlawan. Peristiwa kebahagiaan Totjhe bukan merupakan penutup pada novel Gedhong Setan, akan tetapi terjadi peristiwa yang tidak terduga yakni stresnya Soniahenie akibat trauma yang dialaminya pada saat kejadian di dalam Gedhong Setan.

Definisi latar (setting) menurut Wahyuningtyas \& Santoso (2011: 7 - 8) adalah suatu lingkungan atau tempat terjadinya peristiwa-peristwa dalam karya sastra yang meliputi latar tempat, latar waktu, dan latar sosial. Menurut Sudjiman (1988: 44), latar adalah segala keterangan, petunjuk, pengacuan, yang berkaitan dengan waktu, ruang dan suasana terjadinya peristiwa dalam suatu karya sastra membangun latar cerita. Setelah diklasifikasi secara keseluruhan, novel ini terdiri dari latar tempat, waktu, dan suasana. Latar tempat ditunjukkan dengan menyebut suatu wilayah yakni Gedhong Setan, Pasar Kembang, Kota Surabaya. Untuk latar tempat tinggal rumah tokoh di Tamarindelan terjadi di dalam rumah tokoh antara lain dalam rumah, kamar tidur, dapur, pendapa, halaman rumah. Ada pula latar tempat lainnya di Kota Surabaya tepatnya di sekolahan HBS, Kuburan Cina, Renierz Boulevard, rumah sakit. Latar waktu ditandai keterangan hari, bulan Jawa, serta pembagian waktu dalam sehari (siang, sore, dan malam hari). Latar suasana ditunjukkan dengan peristiwa-peristiwa yang dialami oleh tokoh yang menyiratkan suasana cemas, tidak sabar, ketakutan dan senang.

Bahasa merupakan alat komunikasi untuk berinteraksi antara satu sama lain. Dengan adanya bahasa sebagai alat komunikasi inilah maksud 
penutur dapat tersampaikan. Selain dapat disampaikan secara lisan, bahasa juga disampaikan dengan cara tertulis, salah satu contohnya adalah karya sastra. Dengan tulisan inilah pembaca memahami maksud dari penulis melalui lambang-lambang tulisan yang disampaikan. Dari cara penulisan ini menurut Putra dan Hardiwidjaja (2007: 100) bahwa bahasa menunjukkan ciri khas penulis dari siapa orang dibalik pengarangnya. Dari penggunaan bahasa yang indah, kreatif, serta bahasa yang inovatif memberikan kesan tersendiri bagi pembacanya. Bahasa yang digunakan dalam novel Gedhong Setan karya Suparto Brata ialah bahasa Jawa tengahan sedikit Jawa timuran dan bahasa Belanda. Ciri bahasanya yakni dalam novel ini menggunakan dialek Jawa Tengah-an dan sedikit Jawa timuran. Terakhir, digunakannya ragam bahasa Jawa krama alus digunakan dalam cerita untuk meenunjukkan kepada siapa tokoh sedang berbicara atau menghormati lawan bicara yang lebih tua. Sudut pandang merupakan penempatan posisi pengarang dalam menjelaskan peristiwa dalam cerita. Nurgiyantoro (2005: 256-266) mengklasifikasikan sudut pandang menjadi tiga macam. Pertama, sudut pandang persona pertama memposisikan pengarang terlibat dalam cerita dan berperan sebagai aku. Kedua, sudut pandang persona ketiga (mahatahu) ialah pengarang tidak terlibat dalam cerita dengan menampilan tokoh dengan menyebut dia. Ketiga, sudut pandang campuran menggunakan sudut pandang orang pertama dan ketiga. Sudut Pandang yang digunakan pengarang menggunakan sudut pandang orang ketiga. Hal tersebut dibuktikan dengan tidak adanya peran pengarang dalam cerita, namun pengarang menyebutkan nama-nama tokoh dalam cerita novel.

Karya satra dibuat dengan maksud atau tujuan tertentu. Maksud dan tujuan pembuatan karya sastra tersebut pasti akan mengandung pesan yang akan disampaikan pembuat karya tersebut kepada penikmat sastranya, pesan yang akan disampaikan tersebut sering disebut dengan istlah amanat. Amanat adalah pesan yang akan disampaikan melalui cerita. Amanat baru dapat ditemukan setelah pembaca menyelesaikan seluruh cerita yang dibacanya. Amanat biasanya berupa nilai-nilai yang dititipkan penulis cerita 
kepada pembacanya. Sekecil apa pun nilai-nilai itu pasti ada (Ismawati, 2013: 73).

\section{Struktur Ekstrinsik}

Tokoh Goldmann Ia adalah penggagas pertama yang mencetuskan bahwa karya sastra bisa terbentuk bukan karena faktor internal atau intrinsik saja, namun juga disebabkan oleh faktor eksternalnya atau biasa disebut dengan faktor ekstrinsik. Sedangkan unsur ekstrinsik merupakan unsur pendukung kondisi eksternal dari sudut pengarang yang dapat berupa kondisi ekonomi, sosial budaya, politik, biografi, penerbit, dan lain-lain (Jabrohim. 2014: 82). Situasi sosial politik merupakan salah satu faktor penyebab dan menjadi pengaruh munculnya suatu karya sastra. Seperti halnya karya sastra berupa novel berbahasa Jawa yang lahir karena latar situasi sosial politik. Novel yang ada di era 1960 sampai 1970-an, lahir dengan latar belakang sosial politik berupa seperti latar belakang perebutan kekuasaan atau menurut Utomo (2002: 64) menjelang gerakan pemberontakan PKI. Dalam hal ini Utomo (2002: 65) menyatakan bahwa novel merupakan tempat pelarian (eskapisme) bagi masyarakat yang mengalami situasi ketidakpastian dalam lingkup kehidupan bersama.

Situasi sosial politik, ekonomi, dan budaya merupakan salah satu penyebab munculnya novel. Situasi sosial politik, ekonomi, dan budaya pada waktu 2000-an sudah kondusif dan mengalami perkembangan sehingga memungkinkan untuk membuat sebuah karya satra Jawa modern yaitu Novel Jawa modern. Dari dampak tersebut banyak masyarakat yang haus akan hiburan dan dimunculkanlah novel oleh para pengarang novel terutama Novel Jawa.

Sistem pengarang dan kepengarangan adalah subjek pembuat karya sastra yang merupakan pendukung karya sastra itu sendiri yang memiliki latar belakang status sosial, pendidikan, pekerjaan, asal-usul maupun pengalaman dalam kepengarangan. Menurut Utomo (2002: 79), karya sastra novel tidak terpisahkan dari motivasi seorang penulis. Menurutnya bahwa novel tidak terpisahkan dari kepentingan dagang. Sistem pengarang dan kepengarangan dalam novel banyak didominasi oleh kaum pria. Hanya sedikit pengarang wanita yang ikut andil dalam kepengarangan karya sastra 
novel. Salah satu pengarang pria terkenal yang ikut andil adalah Suparto Brata yang menuliskan novel yang berjudul Gedhong Setan.

Penerbit dan penerbitan merupakan bingkai sastra yang keberadaannya sangat menentukan terhadap perkembangan suatu karya sastra. Dalam proses penerbitan, penerbit mendapatkan, mengubah, mengganti, atau mengontrol informasi yang diproses (Balai Bahasa, 2001: 105). Sistem penerbit dan penerbitan yang terdapat pada novel Gedhong Setan karya Suparto Brata diterbitkan oleh penerbitan NARASI (Anggota IKAPI) yang terdapat di Sumberan Yogyakarta. Selain itu, novel ini juga diterbitkan pada tahun 2010 .

Pada sistem pembaca, sebuah karya sastra ada pastilah terdapat para pembacanya. Seperti karya sastra novel yang diterbitkan dengan menggunakan kertas berkualitas rendah sebagai akibat dari dampak perekonomian di masa itu membuat pangsa pembaca novel ditujukan untuk masyarakat golongan menengah kebawah (Utomo, 2002: 127). Hal tersebut bertujuan agar masyarakat menengah kebawah juga bisa menikmati hiburan sebagai pembaca karya sastra.
Nilai Pendidikan dalam Novel Gedhong Setan Karya Suparto Brata

Darmodiharjo (dalam Setiadi, 2006: 117), mengungkapkan nilai adalah sesuatu yang berguna bagi manusia baik jasmani maupun rohani. Menilai oleh Setiadi (2006: 110) dikatakan sebagai kegiatan yang menghubungkan sesuatu dengan sesuatu yang lain sehingga diperoleh menjadi suatu keputusan yang menyatakan sesuatu itu berguna atau tidak berguna, benar atau tidak benar, baik atau buruk, manusiawi atau tidak manusiawi. Religius atau tidak religius. Pendidikan pada hakikatnya merupakan upaya membantu peserta didik untuk menyadari nilai-nilai yang dimilikinya dan berupaya memfasilitasi mereka agar terbuka wawasan dan perasaannya untuk memiliki dan meyakini nilai yang lebih hakiki, lebih tahan lama, dan merupakan kebenaran yang dihormati dan diyakini secara sahih sebagai manusia yang beradab (Setiadi, 2006: 114). Mengacu pada uraian di atas, dapat ditarik kesimpulan bahwa nilai pendidikan adalah segala sesuatu yang baik maupun buruk yang berguna bagi kehidupan manusia yang diperoleh 
melalui proses pengubahan sikap dan tata laku dalam upaya mendewasakan diri. Nilai pendidikan dapat diperoleh dari pemahaman, pemikiran, dan penikmatan karya sastra.

Nilai pendidikan yang terdapat dalam novel Gedhong Setan karya Suparto Brata ini yakni pertama, nilai keagamaan digambarkan oleh Totjhe yang terus memanjatkan doa agar diberi keslamatan oleh yang maha kuasa. Kedua, Nilai moral yang dapat dilihat dalam novel Gedhong Setan ini adalah seperti rasa cinta tanah air, sikap patuh terhadap orang tua, dan nilai moral lainnya. Setelah membaca isi cerita novel ini, dapat diambil nilai moralnya seperti perjuangan Totjhe dalam menyelesaikan sekolahnya dan tidak mau kalah dengan Bangsa Belanda karena dia pribumi satusatunya yang bisa sekolah di sekolahan Belanda. Ketiga, Sikap saling membutuhkan tersebut merupakan hubungan sebab akibat dari nilai sosial. Nilai sosial yang terdapat dalam novel Gedhong Setan terlihat dari kepedulian Karel Hoekhuys tehadap Totjhe dan temannya Totjhe yang mau meminjami Foto toestel yaitu Martin
Steendam. Selanjutnya, sikap sopan santun dapat dilihat pada dialog para tokoh yang menggunakan undha usuk basa atau tingkat tutur ketika berbicara kepada orang yang lebih tua. Terakhir, nilai budaya yang terdapat dalam novel Gedhong Setan adalah budaya menggunakan bahasa krama atau tingkat tutur untuk menunjukkan rasa hormat kepada orang lain penggunaan bahasa Belanda dalam kehidupan sehari-hari.

\section{Relevansi Novel sebagai Materi Pembelajaran Bahasa Jawa di SMA}

Materi ajar atau Bahan ajar adalah sesuatu yang mengandung pesan yang akan disampaikan dalam proses belajar-mengajar. Bahan ajar dikembangkan berdasarkan tujuan pembelajaran. Bahan ajar sastra yang ideal adalah bahan yang autentik, artinya benar-benar berupa karya cipta sastra. Karya sastra tersebut dapat berupa puisi, cerpen, novel, drama yang ditulis oleh sastrawan atau tulisan sendiri oleh guru (Ismawati, 2013: 35). Karya sastra terdiri atas nasihat, pedoman, dan ajaran dengan harapan agar pembaca dapat meneladani perbuatan yang baik, sebaiknya tidak meniru dan tidak 
melakukan sifat-sifat yang tidak baik. Dalam hubungan ini karya sastra memiliki kesejajaran dengan agama dan sistem kepercayaan lain, budi pekerti dan pendidikan moral yang lain (Ratna, 2014: 175). Mashita, Gani, \& Bakhtaruddin (2013: 86) mengungkapkan bahwa nilai pendidikan dalam karya sastra digali berdasar aspek karya sastra itu sendiri. Novel merupakan bentuk karya sastra sebagai refleksi kehidupan yang diendapkan melalui perenungan, pengimajinasian dan kreativitas oleh penyair sehingga menghasilkan sebuah karya yang indah dan dapat dinikmati oleh pembaca atau penikmat satra.

Materi membaca novel di SMA merupakan materi wajib yang harus diajarkan pada siswa kelas XI. Hal ini tertera pada silabus mata pelajaran bahasa Jawa SMA kelas XI pada Kompetensi Dasar (KD) membaca novel. Oleh sebab itu, materi membaca novel harus diajarkan pada siswa karena sudah termuat dalam silabus mata pelajaran bahasa Jawa. Berkaitan dengan pengajaran tersebut, novel Gedhong Setan karya Suparto Brata ini dapat dijadikan sebagai materi pembelajaran bahasa Jawa untuk siswa
SMA kelas XI. Digunakannya novel sebagai bahan pembelajaran khususnya novel berbahasa Jawa diharapkan siswa dapat mengenal karya sastra Jawa yang merupakan warisan jaman dahulu. Penggunaan kosakata yang biasa digunakan dalam novel ini mudah untuk dipahami siswa sebab menggunakan bahasa Jawa ngoko serta dapat menambah kosa kata bahasa Jawa untuk siswa. Selain itu, penggunaan tema perjuangan, percintaan dan kasih sayang keluarga cocok untuk siswa SMA. Hal ini selaras dengan pendapat ahli sastra, Djoko Sulakono, bahwa novel Gedhong Setan karya Suparto Brata relevan dijadikan sebagai materi pembelajaran bahasa Jawa. Menurutnya tema perjuangan yang diangkat dalam cerita bagus untuk anak SMA. Namun, untuk tema percintaan tergantung dari sudut pandang pembaca dan kedalaman penulis dalam menyatakan halhal percintaan tersebut. Pendapat yang sama juga diutarakan oleh guru mata pelajaran bahasa Jawa di SMA Negeri 2 Surakarta bahwa novel ini layak digunakan sebagai materi pembelajaran bahasa Jawa tingkat SMA. Menurutnya, karena novel tersebut su- 
dah dipadatkan isinya, jadi lebih memudahkan siswa untuk memahami.

Sejalan dengan pendapatpendapat di atas, berkaitan dengan pemilihan materi ajar untuk siswa jenjang SMA terdapat penelitian yang relevan dengan penelitian ini. Penelitian tersebut dilakukan oleh Meilindasari (2015) dengan judul "Analisis Struktural dan Nilai Pendidikan Novel Kembang Kantil Karya Senggono serta Relevansinya sebagai Materi Pembelajaran Bahasa Jawa Di SMA". Penelitian tersebut menghasilkan simpulan bahwa novel tersebut memiliki struktur pembangun yang lengkap serta nilai pendidikan yang dapat diajarkan untuk siswa. Selain itu, penelitian tersebut mengungkapkan bahwa bahan kajiannya berupa novel Jawa Kembang Kantil karya Senggono dapat dijadikan sebagai alternatif materi pada pembelajaran bahasa Jawa membaca novel. Berkaitan dengan hal tersebut, kebaruan dari penelitian ini mengenai novel Gedhong Setan dapat dijadikan sebagai bahan materi pembelajaran bahasa Jawa untuk jenjang SMA. Selain itu, terdapat perbedaan lainnya yaitu pada objek kajiannya.
Tidak semua novel berbahasa Jawa dapat digunakan sebagai bahan ajar untuk siswa. Dengan demikian, pemilihan bahan ajar yang tepat dapat memaksimalkan proses dan hasil belajar siswa.

\section{KESIMPULAN}

Berdasarkan hasil analisis dan pembahasan di atas penelitian ini dapat disimpulkan sebagai berikut. Pertama, struktur intrinsik novel Gedhong Setan terdiri dari tema, tokoh dan penokohan, alur, latar, bahasa, dan sudut pandang. Pengklasifikasian tokoh dan penokohan terdapat tiga bagian, yaitu tokoh sentral (protagonis dan antagonis), tokoh bawahan, dan tokoh-tokoh lain. Tema yang terdapat dalam novel Gedhong Setan ini adalah sosial mengenai menepati janji, percintaan, perjuangan, dan kasih sayang keluarga. Secara keseluruhan terdapat dua puluh tokoh yang muncul dalam novel Gedhong Setan karya Suparto Brata. Tokoh sentral yang terdapat dalam novel adalah tokoh Totjhe, Mami, Soniahennie, dan Jaan van Vliet. Klasifikasi tokoh bawahan dalam novel ini diperankan oleh Hendriks de Zwarver, Bram de Jong, Karel 
Hoekyus, Martin Steendam. Tokohtokoh lain yang terdapat dalam novel Gedhong Setan antara lain Tineke, Henriette, Ivonny, Bob Roedmaker, Pak Polisi, Pak dokter, Rama, Meneer Heuvelman, Ben Rosenberg, Wong lanang wadon Jepang.

Alur yang digunakan oleh pengarang dalam novel ini adalah alur campuran yakni alur maju dan alur mundur. Penyelesaian cerita dalam novel ini adalah happy ending (cerita berakhir bahagia). Penyelesaian konflik di dalam cerita Novel tersebut ditandai dengan masuknya Sidharta/Totjhe bersama kedua temannya yaitu soniahennie dan Jan Van Vliet ke dalam Gedhong Setan serta diakhiri dengan terbangunnya Totjhe di Rumah Sakit yang disambut bak pahlawan oleh keluarga, teman-temannya serta para polisi dan diberikannya sebuah penghargaan kepada Totjhe.

Terdapat tiga latar dalam cerita, yaitu latar tempat, latar waktu, dan latar suasana. Latar yang terdapat dalam novel Gedhong Setan ini terdapat latar tempat yang secara umum terjadi Gedhong Setan serta di Rumah Totjhe Tamarindelaan, Pasarkembang, Kampung Kupang Panjaan Kota
Surabaya. Latar waktu yang terdapat dalam novel ini antara lain pada waktu pagi, siang, sore, dan malam hari. Selanjutnya latar suasana ditunjukkan dengan peristiwa-peristiwa yang dialami oleh tokoh seperti, cemas dan gembira. Bahasa yang digunakan dalam narasi cerita adalah bahasa Jawa ragam ngoko dan sedikit krama serta bahasa belanda. Sudut pandang yang digunakan pengarang menggunakan sudut pandang orang ketiga mahatahu. Amanat yang terdapat pada novel Gedhong Setan adalah agar selalu memperjuangkan harkat dan martabat bangsa dan lebih mengutamakan pendidikan serta patuh terhadap kedua orang tua.

Selain unsur intrinsik, terdapat pula struktur ekstrinsik yang melatar belakangi adanya sebuah karya sastra novel. Unsur ekstrinsik pembentuk novel Gedhong Setan karya Suparto Brata adalah situasi sosial politik, ekonomi, dan budaya; Situasi sosial politik, ekonomi, dan budaya merupakan salah satu penyebab munculnya novel. Situasi sosial politik, ekonomi, dan budaya pada waktu 2000an sudah kondusif dan mengalami perkembangan sehingga memungkinkan untuk membuat sebuah karya sastra 
Jawa modern. Dari dampak tersebut banyak masyarakat yang haus akan hiburan dan dimunculkanlah novel oleh para pengarang novel berbahasa Jawa, salah satunya adalah Gedhong Setan

Sistem pengarang dan kepengarangan adalah subjek pembuat karya sastra yang merupakan pendukung karya sastra itu sendiri yang memiliki latar belakang status sosial, pendidikan, pekerjaan, asal-usul maupun pengalaman dalam kepengarangan. Pengarang novel Gedhong Setan ini ialah Suparto Brata. Untuk sistem penerbit dan penerbitan; novel ini diterbitkan pada tahun 2010 oleh NARASI (Anggota IKAPI) di Sumberan Yogyakarta. Sistem pembaca; untuk pembaca novel ini ditujukan pada semua kalangan, khususnya anak-anak remaja.

Kedua, nilai pendidikan yang terdapat dalam novel Gedhong Setan karya Suparto Brata ini yakni, nilai keagamaan dan nilai sosial digambarkan oleh Totjhe yang terus memanjatkan doa agar diberi keslamatan oleh yang maha kuasa. Setelah membaca isi cerita novel ini, dapat diambil nilai moralnya seperti perjuangan Totjhe dalam menyelesaikan sekolahnya dan tidak mau kalah dengan Bangsa Belanda karena dia pribumi satu-satunya yang bisa sekolah di sekolahan Belanda. Nilai sosial yang terdapat dalam novel Gedhong Setan terlihat dari kepedulian Karel Hoekhuys tehadap Totjhe dan temannya Totjhe yang mau meminjami foto toestel, yaitu Martin Steendam. Selanjutnya, sikap sopan santun dapat dilihat pada dialog para tokoh yang menggunakan undha usuk basa atau tingkat tutur ketika berbicara kepada orang yang lebih tua. Terakhir, nilai budaya yang terdapat dalam novel Gedhong Setan adalah budaya menggunakan bahasa krama atau tingkat tutur untuk menunjukkan rasa hormat kepada orang lain penggunaan bahasa Belanda dalam kehidupan sehari-hari.

Ketiga, Materi ajar atau Bahan ajar adalah sesuatu yang mengandung pesan yang akan disampaikan dalam proses belajar-mengajar. Bahan ajar dikembangkan berdasarkan tujuan pembelajaran. Bahan ajar sastra yang ideal adalah bahan yang autentik, artinya benar-benar berupa karya cipta sastra. Karya sastra tersebut dapat berupa puisi, cerpen, novel, drama yang ditulis oleh sastrawan atau tulisan 
sendiri oleh guru (Ismawati, 2013: 35). Berdasarkan simpulan-simpulan di atas novel Gedhong Setan karya Suparto Brata dapat digunakan sebagai materi ajar pembelajaran bahasa Jawa di SMA karena banyak mengndung pesan moral dan nilai pendidikan dan sesuai dengan kurikulum 2013 yang terdapat dalam silabus SMA kelas XI. Di dalam silabus tersebut menerangkan adanya standar kompetensi mengenai novel bahasa Jawa dan kompetensi dasar dalam menemukan unsur-unsur pembangun novel dan nilai-nilai yang terkandung di dalamnya. Dari segi struktur, novel Gedhong Setan memiliki struktur yang lengkap serta memiliki nilai-nilai pendidikan yang dapat dijadikan motivasi dan diaplikasikan dalam kehidupan sehari-hari siswa. Dengan demikian, selain dapat memenuhi indikator pembelajaran, novel ini juga dapat memberikan pelajaran kehidupan melalui penggambaran tokoh dalam cerita.

\section{DAFTAR PUSTAKA}

Asmani, Jamal Ma'mur. (2011). Metodologi Praktis Penelitian Pendidikan. Yogyakarta: Diva Press.

Balai Bahasa Yogyakarta. (2001). Ikhtisar Perkembangan Sastra Jawa Modern Periode Kemerdekaan. Yogyakarta: Kalika Press.

Bodgan, Robert \& Steven J. Taylor. (1993). Kualitatif (Dasar-Dasar Penelitian). (ter. A. Khozin Afandi). Surabaya: Usaha Nasional.

Ismawati, Esti. (2013). Pengajaran Sastra. Yogyakarta: Ombak.

Jabrohim. 2014. Teori Penelitian Sastra. Yogyakarta: Pustaka Pelajar

Mashita, Mutia., Gani, Erizal., \& Bakhtaruddin. (2013). "Nilai-nilai Pendidikan dalam Novel Sepatu Dahlan Karya Khrisna Pabichara dan Implikasinya dalam Pembelajara Bahasa Indonesia". Jurnal Pendidikan Bahasa dan Sastra Indonesia, 1 (2), 85-94. Diperoleh 13 Oktober 2015, dari http;//jurnal.unp.ac.id.

Meilindasari, Dyah Ayu. (2015). “Analisis Struktural dan Nilai Pendidikan Novel Kembang Kantil Karya Senggono serta Relevansinya sebagai Materi Pembelajaran Bahasa Jawa Di SMA”. Skripsi. Universitas Sebelas Maret.

Miles, M. B. \& Hubermen, A. M. (1992). Analisis Data Kualitatif: Buku Sumber tentang Metode-metode Baru. Terjemahan Tjetjep Rohendi Rosidi. Jakarta: UI Press.

Moleong, L. J. (2001). Metodologi Penelitian Kualitatif. Bandung: Remaja Rosdakarya. 
Nurgiyantoro, B. (2013). Teori Pengkajian Fiksi. Yogyakarta: Gadjah Mada University Press.

Pradopo, R. D. (2013). Ragam Bahasa Sastra. Yoyakarta: Hanindita Graha Widya.

Putra, M.S. \& Hardiwidjaja, Y. (2007). How To Write and Market Novel. Bandung: Kolbu.

Ratna, Nyoman Kutha. (2014). Peranan Karya Sastra, Seni, dan Budaya dalam Pendidikan Karakter. Yogyakarta: Pustaka Pelajar.

Rohman, Muhammad dan Amri, Sofan. (2013). Strategi dan Desain Pengembangan Sistem Pembelajaran. Jakarta: Prestasi Pustaka.

Rokhmansyah, A. (2014). Studi Pengkajian Sastra Perkenalan Awal Terhadap Ilmu Sastra. Yogyakarta: Graha Ilmu.

Semi, M. Atar. (1993). Anatomi sastra. Padang: Angkasa Raya.

Setiadi, M. Elly. (2006). Ilmu Sosial dan Budaya Dasar. Jakarta: Kencana.

Setyawati, Rita. (2013). "Struktur dan Nilai Pendidikan dalam Novel Kerajut Benang Ireng Karya Harwimuka", Jurnal Pendidikan, Bahasa, Sastra, dan Budaya Jawa_Universitas Muhammadiyah Purworejo, 3 (01), 1-6, Diperoleh 13 Oktober 2015, dari http://jurnal.ump.ac.id.

Sudjiman, Panuti. (1988). Memahami Cerita Rekaan. Jakarta: Pustaka Jaya.

Suroto. (1990). Apresiasi Sastra Indonesia. Jakarta: Erlangga.

Sutopo, H. B. (2002). Metodologi Penelitian Kualitatif. Surakarta: UNS Pres.

Suwondo, T . 2001. "Analisis Struktural Salah Satu Metode Pendekatan dalam Penelitian Sastra" dalam Jabrohim dan Wulandari (Ed.). Metodologi Penelitian sastra. Yogyakarta : Hanindita Graha Widya.

Utomo, Imam Budi, (2002). Eskapisme Sastra Jawa. Yogyakarta: Gama Media.

Wahyuningtyas, Sri \& Santosa, Wijaya Heru. (2011). Sastra: Teori dan Implementasi. Surakarta: Yuma Pustaka.

Waluyo, H. J. (1994). Pengkajian Cerita Fiksi. Surakarta: Sebelas Maret University Press.

Zuldafrial \& Muhammad Lahir. (2012). Penelitian Kualitatif. Surakarta: Yuma Pustaka. 